BUSTANUL FUQAHA: Jurnal Bidang Hukum Islam

Vol. 1, No. 1 (2020) : Hal. 79-92

Website: https://journal.stiba.ac.id

\title{
HUKUM DAN URGENSI WAKAF TUNAI DALAM TINJAUAN FIKIH
}

\author{
Asri \\ Sekolah Tinggi Ilmu Islam dan Bahasa Arab (STIBA) Makassar \\ Email: asridaeng1@stiba.ac.id \\ Khaerul Aqbar \\ Sekolah Tinggi Ilmu Islam dan Bahasa Arab (STIBA) Makassar \\ Email: khaerul@stiba.ac.id \\ Azwar Iskandar \\ Sekolah Tinggi Ilmu Islam dan Bahasa Arab (STIBA) Makassar \\ Email: azwar@stiba.ac.id
}

\begin{abstract}
Keywords :
waqf, cash, law, urgency, This study aimed at determining the law and urgency of cash economy

waqf in fiqh point of view in accordance with some views of fiqh scholars related to cash waqf. This research used a qualitativedescriptive approach with content analysis techniques and library research. The results showed that the scholars hold different views in deciding the law of cash waqf. Some scholars hold that the cash waqf is permissible. Some others hold that it is makruh (undesirable). There are even some scholars who forbid it. The author inclines toward the view that asserts its permissibility. The urgency and target of cash waqf is improvement of the economy and benefit in the world and the hereafter.
\end{abstract}

\begin{tabular}{|c|c|c|}
\hline Kata kunci : & & ABSTRAK \\
\hline $\begin{array}{l}\text { wakaf, tunai, } \\
\text { urgensi, ekonomi }\end{array}$ & hukum, & $\begin{array}{l}\text { Penelitian ini bertujuan untuk mengetahui hukum dan urgensi } \\
\text { wakaf tunai dalam tinjauan fikih, dengan melihat beberapa } \\
\text { pandangan ulama fikih terkait wakaf tunai tersebut. Penelitian } \\
\text { ini menggunakan metode pendekatan kualitatif-deskriptif } \\
\text { dengan teknik content analysis (analisis isi) dan riset } \\
\text { kepustakaan (library research). Hasil penelitian menunjukkan } \\
\text { bahwa para ulama berbeda pendapat dalam menetapkan hukum } \\
\text { tentang wakaf tunai. Sebagian di kalangan ulama berpendapat } \\
\text { akan bolehnya wakaf tunai tersebut. Sebagian yang lainnya } \\
\text { memandang hukumnya makruh. Bahkan adapula ulama yang } \\
\text { mengharamkannya. Adapun penulis lebih cenderung kepada } \\
\text { pendapat yang menyatakan akan kebolehannya. Adapun urgensi } \\
\text { dan sasaran dari wakaf tunai adalah untuk meningkatkan } \\
\text { perekonomian dan mendapatkan kemaslahatan di dunia dan } \\
\text { akhirat. }\end{array}$ \\
\hline
\end{tabular}




\section{PENDAHULUAN}

Wakaf merupakan salah satu akad tabarru' yang dikenal dalam ilmu fikih. Akad ini memiliki peran yang sangat besar dalam pembangunan infrastruktur pada berbagai macam fasilitas umum dan pemberdayaan ekonomi umat.

Salah satu pembahasan yang menarik dalam wakaf ini adalah pembahasan tentang wakaf tunai, yang sebelumnya tidak populer di zaman Nabi shallallahu 'alaihi wasallam dan para sahabat, tetapi sudah mulai diperbincangkan oleh sebagian ulama pada masa setelahnya yaitu utamanya di kalangan tabi'in.

Wakaf tunai adalah satu alternatif yang diharapkan dapat mengatasi permasalahan kemiskinan di tengah masyarakat, dengan adanya partisipasi aktif dari pihak non pemerintah (masyarakat), khususnya golongan kaya dan memiliki kemampuan untuk membantu meringankan penderitaan masyarakat miskin. Apabila potensi masyarakat yang kaya ini dapat dikoordinasikan dan dikelola dengan baik, hal ini akan memberikan alternatif kontribusi positif terhadap pengangulangan masalah kemiskinan tersebut di atas.

Salah contoh di Bangladesh, upaya non pemerintah untuk menjawab masalah kemiskinan telah dicoba dijawab melalui keberadaan lembaga yang bernama Social Investment Bank Limited (SIBL) ${ }^{1}$. Lembaga ini beroperasi dengan menggalang dana masyarakat (kaya), khususnya melalui dana wakaf tunai, untuk kemudian dikelola dan hasil pengelolaannya disalurkan untuk masyarakat miskin.

Pada kasus di Indonesia, upaya seperti yang dilakukan oleh SIBL tersebut, merupakan satu alternatif yang menarik dan patut untuk diakomodir. Dengan jumlah penduduk muslim yang mayoritas, upaya penggalangan dan pengelolaan dana wakaf (tunai) seperti halnya di Bangladesh, diharapkan dapat lebih terapresiasikan oleh masyarakat (muslim), minimal secara kultural.

Di sisi lain, keberadaan institusi-institusi syariah (khususnya perbankan) merupakan lembaga alternatif yang representatif untuk mengelola dana-dana amanah tersebut. Di samping itu, dana-dana tersebut juga merupakan salah satu sumber dana bagi perbankan (lembaga keuangan) syariah, yang secara prinsip telah terakomodasi di dalam ketentuan perbankan syariah.

Berdasarkan latar belakang tersebut, maka hal yang perlu dikaji dan diteliti oleh penulis sebagai rumusan masalah dalam penelitian ini adalah bagaimana hukum dan urgensi wakaf tunai dalam tinjauan fikih. Sehingga tujuan dari penelitian ini adalah untuk mengetahui hukum dan urgensi wakaf tunai dalam tinjauan fikih, dengan melihat beberapa pandangan ulama fikih terkait wakaf tunai tersebut. Penelitian ini menggunakan metode pendekatan kualitatif-deskriptif dengan teknik content analysis (analisis isi) dan riset kepustakaan (library research). Teknik content analysis merupakan metode penelitian yang digunakan untuk mengetahui simpulan dari sebuah teks. Atau dengan kata lain, analisis isi merupakan metode penelitian yang ingin mengungkap gagasan penulis yang termanifestasi maupun yang laten. Sementara riset kepustakaan (library research) pada penelitian ini mengunakan jenis dan sumber data sekunder yang

${ }^{1}$ https://www.siblbd.com/retail/deposit_details/Cash-Waqf-Deposit 
diperoleh dari hasil penelitian, artikel dan buku-buku referensi yang membahas topik yang berkaitan dengan tema penelitian².

Dalam tulisan ini akan dibahas tentang hukum wakaf tunai dari berbagai perspektif ulama dari berbagai mazhab berikut urgensi dan sasarannya. Berkaitan dengan pembahasn wakaf tunai, terdapat beberapa penelitian terdahulu yang berkaitan dengan wakaf tunai ini dari berbagai sudut pandang.

Muhammad Tho'in dan Iin Emy Prastiwi ${ }^{3}$ melakukan penelitian yang bertujuan untuk mengetahui lebih mendalam tentang wakaf tunai secara rinci dalam syariat. Adapun hasil dari penelitian tersebut menunjukkan bahwa sistem wakaf merupakan konsep yang tidak secara jelas dan tegas disebutkan dalam al-Qur'an dan hadis. Berbeda dengan zakat yang secara jelas disebutkan di dalam al-Qur'an. Imam al-Bukhari (wafat tahun $2526 \mathrm{H}$ ) mengungkapkan bahwa Imam al-Zuhri (wafat tahun $124 \mathrm{H}$ ) berpendapat dinar dan dirham (keduanya mata uang yang berlaku di Timur Tengah) boleh diwakafkan. Hal itu berarti bolehnya wakaf dalam bentuk uang (wakaf tunai). Mazhab Hanafi juga membolehkan wakaf tunai sebagai pengecualian, atas dasar istihsan bi al'urfi (adat kebiasaan), karena sudah banyak dilakukan masyarakat, dilakukan dengan cara menjadikannya modal usaha dengan cara mudharabah sedang keuntungannya disedekahkan kepada pihak wakaf. Sedangkan menurut al-Bakri, mazhab Syafi'i tidak membolehkan wakaf tunai, dan ada sebagian pengikut mazhab Syafi'i yang membolehkan wakaf tunai. Ulama berpandangan mengenai objek wakaf bahwa syaratsyarat benda wakaf harus merupakan benda, bermanfaat, tidak sekali pakai, tidak haram zatnya dan harus milik wakif secara sempurna. Wakaf tunai tidak dibahas di dalam hadis secara khusus, dan menggunakan ayat-ayat al-Qur'an dan hadis bersifat umum. Oleh karena itu, penentuan syarat-syarat objek wakaf termasuk wilayah ijtihadi.

Moh. Hatta ${ }^{4}$ melakukan penelitian dengan tujuan untuk mengetahui tujuan, fungsi, rukun dan syarat, dasar hukum, tata cara, dan hukum wakaf tunai dalam perspektif ulama mujtahid. Adapun hasil penelitian dari penulisan tersebut bahwa wakaf tunai adalah wakaf yang dilakukan seseorang, kelompok orang, dan lembaga atau badan hukum dalam bentuk uang tunai, yang dipandang sebagai salah satu solusi produktif. Wakif yang akan mewakafkan uangnya wajib hadir di Lembaga Keuangan Syariah Wakaf Uang (sebagai nazhir) yang telah ditunjuk oleh Menteri Agama berdasarkan saran dan pertimbangan dari Badan Wakaf Indonesia. Keberadaan model wakaf tunai dirasakan perlu sebagai instrumen keuangan alternatif yang dapat mengisi kekurangankekurangan badan sosial yang telah ada, yaitu melalui lembaga wakaf yang dimanfaatkan guna keperluan ibadah atau kesejahteraan umum menurut syariah.

2 Azwar Iskandar dan Khaerul Aqbar, "Reposisi Praktik Ekonomi Islam: Studi Kritis Praktik Ekonomi Islam di Indonesia”, NUKHBATUL 'ULUM: Jurnal Bidang Kajian Islam, 5(1), 39-53 (2019): h.39-53.

3 Muhammad Tho'in dan Iin Emy Prastiwi, “Wakaf Tunai Perspektif Syariah”, Jurnal Ilmiah Ekonomi Islam, Vol. 01, No. 01 (Maret 2015): h. 61-74.

${ }^{4}$ Moh. Hatta, "Wakaf Tunai dalam Perspektif Ulama Mujtahid”, Jurnal Al-Qānūn, Vol. 20, No. 2 (Desember 2017): h. 104-121. 
Mustafa Kamal ${ }^{5}$ melakukan penelitian yang bertujuan untuk mengetahui seputar wakaf tunai menurut fikih Syafi'iyyah dan fatwa MUI yang berdasarkan pada pertimbangan ulama Syafi'iyyah dan MUI dalam memahami dalil tentang wakaf tunai. Adapun hasil dari penelitian tersebut menunjukkan bahwa secara garis besar terdapat kesamaan persepsi tentang wakaf di kalangan Syafi'iyyah dan MUI. Namun demikian, dari rumusan tersebut pada pemahaman substansinya terdapat perbedaan. Hukum wakaf uang menurut fatwa MUI boleh (jawaz) atau sah. Penetapan hukum sah wakaf tunai tersebut karena memang terdapat beberapa dasar pertimbangan yang dianggap oleh MUI sangat esensial. Sedangkan golongan Syafi'iiyah memandang uang adalah benda yang hanya dapat dijadikan sebagai alat tukar saja yang dapat punah setelah pemanfaatannya, sehingga menganggap tidak adanya wakaf tunai dalam syariat Islam.

M. Wahib Aziz ${ }^{6}$ melakukan penelitian dengan tujuan untuk mengetahui wakaf tunai menurut Imam Mazhab, operasional dan mekanisme wakaf tunai, dan perbedaan wakaf tunai dan sedekah, serta pembahasan wakaf tunai secara menyeluruh dalam Islam. Adapun hasil penelitian ini menunjukkan bahwa potensi wakaf tunai sangat besar dan mempunyai prospek yang sangat cerah. Jika program wakaf tunai dijalankan secara optimal, maka akan meningkatkan kesejahteraan umat Islam, Hukum wakaf tunai (cash waqf) adalah sunnah (dianjurkan). Wakaf tunai ini perlu disosialisasikan lebih lanjut. Manajemen pelayanan wakaf tunai hendaknya lebih profesional serta pemerintah hendaknya ikut aktif membantu menyukseskan program wakaf tunai ini, mengingat potensi wakaf sangat besar.

Martini Dwi Pusparini ${ }^{7}$ melakukan penelitian dengan tujuan untuk mengetahui konsep wakaf tunai menurut Abdul Mannan, serta manajemen dan perkembangan wakaf tunai. Adapun hasil penelitian ini menunjukkan bahwa menurut Abdul Mannan, wakaf tunai memiliki arti yang sangat penting bagi perekonomian negara, sebagai sarana transfer harta kekayaan orang kaya kepada para pengusaha dan warga masyarakat dalam membiayai berbagai program keagamaan, sosial, dan pendidikan di negara-negara Islam. Wakaf tunai juga dapat berfungsi sebagai investasi yang strategis untuk menghapuskan kemiskinan dan menangani ketertinggalan dalam bidang ekonomi, kesehatan, dan riset. Wakaf tunai di beberapa negara Islam juga menggantikan sebagian besar pajak penghasilan untuk pendanaan proyek-proyek sosial.

M. Anwar Nawawi ${ }^{8}$ melakukan penelitian yang bertujuan untuk mengetahui wakaf uang tunai menurut pandangan ulama konvensional dan kontemporer, serta potensi dan manajemen wakaf tunai dalam memberdayakan ekonomi umat di Indonesia.

${ }^{5}$ Mustafa Kamal, "Wakaf Tunai Menurut Pandangan Fiqh Syafi'iyah dan Fatwa Majelis Ulama Indonesia No. 2 Tahun 2002 Tentang Wakaf Uang”, Jurnal Ilmiah Islam Futura, Vol. 15. No. 1 (Agustus 2015): h. 93-110.

${ }^{6}$ M. Wahib Aziz, "Wakaf Tunai dalam Perspektif Hukum Islam”, Internasional Journal Ihya' 'Ulum al-Din, Vol. 19, No. 1 (2017): h. 1-24. DOI: 10.21580/ihya.18.1.1740

${ }^{7}$ Martini Dwi Pusparini, “Konsep Wakaf Tunai dalam Ekonomi Islam:

Studi Pemikiran Abdul Mannan”, Falah: Jurnal Ekonomi Syariah, Vol. 1, No. 1 (Februari 2016): h. 15-28.

${ }^{8}$ M. Anwar Nawawi, "Pengembangan Wakaf Uang Tunai sebagai Sistem Pemberdayaan Umat dalam Pandangan Ulama Konvensional dan Kontemporer”, Jurnal Fikri, Vol. 1, No. 1 (Juni 2016): h. 183-210. 


\section{BUSTANUL FUQAHA: Jurnal Bidang Hukum Islam}

Vol. 1, No. 1 (2020) : Hal. 79-92

Website: https://journal.stiba.ac.id

Adapun hasill penelitian dalam penulisan ini menunjukkan bahwa dalam sejarah Islam wakaf tunai (cash waqf) telah dipraktikkan sejak dahulu, sejak abad kedua Hijriyah. Ulama klasik dan ulama kontemporer secara keseluruhan membolehkan wakaf uang/wakaf tunai produktif. Kebolehan wakaf tunai dikemukakan oleh mazhab Hanafiyyah dan Malikiyyah. Bahkan sebagian ulama mazhab Syafi'iyyah juga membolehkan wakaf tunai sebagaimana yang disebutkan oleh al-Mawardy. Sedangkan kebolehan wakaf tunai menurut MUI tidak bertentangan dengan definisi wakaf yang telah dirumuskan oleh mayoritas ulama dengan merujuk kepada hadis-hadis tentang wakaf. Dengan adanya UU No. 41 Tahun 2004, maka kedudukan wakaf uang semakin jelas, tidak saja dari segi fikih, tetapi juga dari segi tata hukum nasional.

Dalam beberapa pembahasan tentang wakaf tunai pada penelitian sebelumnya tersebut, penulis tidak melihat adanya penyertaan dalil yang terperinci dalam permaslahan hukum wakaf tunai, sehingga dalam penelitian ini penulis melakukan penelitian lanjutan dengan memberikan rincian dalil masing-masing pendapat ulama fikih. Hal itulah yang kemudian menjadi pikiran pembeda pada penelitian ini. Penulis juga menambahkan penjelasan akan urgensi dan sasaran dari wakaf tunai dalam penelitian ini.

\section{PEMBAHASAN}

\section{Definisi Wakaf}

Wakaf adalah pecahan kata dari kata kerja bahasa Arab “waqafa” (وقف) atau “awqafa” (أوقف) yang sepadan maknanya dengan "habasa" yang berarti menahan atau berhenti. ${ }^{9}$

Dalam istilah Islam, ada beberapa definisi yang disebutkan oleh para ulama dari berbagai mazhab. Al-Imam al-Sarkhasyi mengatakan berkaitan dengan wakaf: "Menahan kepemilikan benda dari pengalihan kepemilikan kepada pihak lain..."10. Ibnu "Arafah dari kalangan Malikiyyah mendefinisikan wakaf: "Memberikan manfaat suatu benda selama keberadaannya, yang harus tetap berada dalam kepemilikan yang memberi. ${ }^{11}$ Adapun dari kalangan Syafi'iyyah, al-Baidhawiy mendefinisikan: "Menahan asal dan memberikan manfaat", begitu juga dengan Ibnu Qudamah dari Hanabilah memberikan definisi yang sama dengan definisi di atas ${ }^{12}$.

\section{Dasar Hukum Wakaf diambil dari al-Qur'an, al-Sunnah, dan Ijmak Ulama}

${ }^{9}$ Muhammad Mukarram Ibnu Manzhur, Lisanul Arab, Jilid IX, (Beirut: Dar Shadir, 1414 H), h. 359.

${ }^{10}$ Muhammad bin Abi Sahal al-Sarkhasiy, Al-Mabsuth, Jilid XII, (Beirut: Dar al-Ma'rifah, 1406 H), h. 27.

${ }^{11}$ Muhammad bin Muhammad bin Abdurrahman al-Maghribiy, Mawahib al-Jalil Syarh alMukhtshar al-Jalil, Jilid VI, (Kairo: Dar al-Fikr, 1412 H/ 1992 M), h. 18.

12 Abdullah bin Ahmad Ibnu Qudamah al-Maqdisi, Al-Mughniy, Jilid VI, (Riyadh: Maktabah al-Riyadh al-Hadisah, 1401 H/ 1981 M), h. 185. 
Landasan atau dasar hukum wakaf diambil dari al-Qur'an, al-Sunnah dan ijmak ulama. Ta'ala:

Adapun dari al-Qur'an, maka di antaranya adalah keumuman Firman Allah

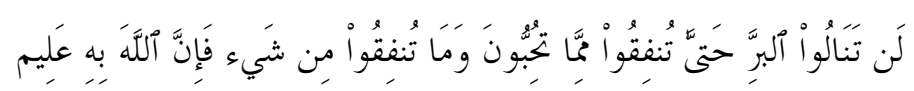

Terjemahnya: "Kamu sekali-kali tidak sampai kepada kebajikan (yang sempurna), sebelum kamu menafkahkan sebahagian harta yang kamu cintai. Dan apa saja yang kamu nafkahkan, maka sesungguhnya Allah Mengetahuinya." (Q.S. Ali Imran: 92)

Adapun dari al-Sunnah maka di antaranya adalah Sabda Rasulullah shallallahu 'alaihi wasallam:

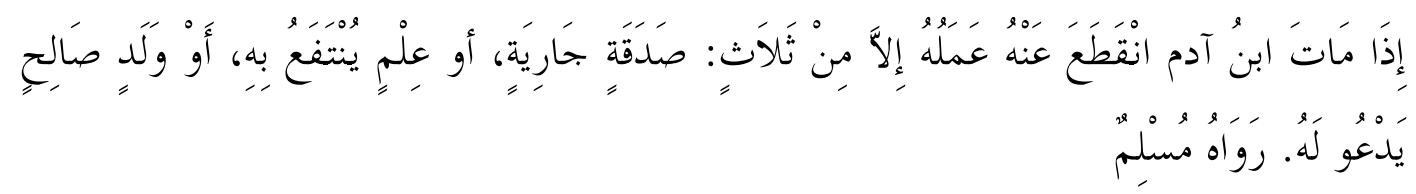

Artinya: “Apabila manusia wafat, terputuslah amal perbuatannya, kecuali dari tiga hal, yaitu sedekah jariyah, ilmu pengetahuan yang dimanfaatkan atau anak yang saleh." 13

Wakaf masuk dalam keumuman sedekah jariyah dalam hadis ini. Bahkan wakaf mulai dipraktikkan dalam masyarakat Islam sejak masa Rasulullah shallallahu 'alaihi wasallam. Di antara buktinya ialah wakaf Umar bin Khattab radhiyallahu 'anhu.

Hal ini sebagaimana yang diriwayatkan oleh Imam al-Bukhari dan Imam Muslim dalam al-Shahihain dari sahabat Abdullah bin Umar, bahwa Umar bin Khattab mendapat sebidang tanah di Khaibar. Lalu Umar bin Khattab menghadap Rasulullah untuk memohon petunjuk beliau tentang apa yang sepatutnya dilakukannya terhadap tanahnya tersebut. Umar berkata kepada Rasulullah: "Ya Rasulullah, saya mendapat sebidang tanah di Khaibar dan saya belum pernah mendapat harta lebih baik dari tanah di Khaibar itu. Karena itu saya memohon petunjuk Rasulullah tentang apa yang sepatutnya saya lakukan pada tanah itu". Rasulullah menjawab, "Jika anda mau, tahanlah tanahmu itu dan anda sedekahkan". Lalu Umar mensedekahkannya dan mensyaratkan bahwa tanah itu tidak boleh dijual, dihibahkan dan diwariskan. Umar salurkan hasil tanah itu buat orang-orang fakir, kerabat-kerabat, pembebasan budak, orang-orang yang berjuang fi sabilillah, orang-orang yang kehabisan bekal dalam perjalanan dan tamu. Pengurus wakaf itu sendiri, boleh makan dari hasil wakaf tersebut dalam batas-batas yang ma'ruf (biasa). Ia juga boleh memberi makan orang lain dari wakaf tersebut dan tidak bertindak sebagai pemilik harta sendiri”. ${ }^{14}$

${ }^{13}$ Muslim bin Hajjaj al-Naisaburi, Shahih Muslim, Jilid V, (Beirut: Dar Ihya' al-Turats alArabi, 1954 M), h. 1255.

${ }^{14}$ Muhammad bin Ismail al-Bukhariy, Shahih al-Bukhariy, Jilid III, (Beirut: Dar Tauq alNajah, 1422 H), h. 198. Lihat juga; Muslim bin Hajjaj al-Naisaburi, Shahih Muslim, Jilid III, (Beirut: Dar Ihya' al-Turats al-Arabi, 1954 M), h. 1255. 
Ada beberapa beberapa kesimpulan penting dari hadis di atas, di antaranya adalah sebagai berikut:

a. Hadis ini menjadi dasar sahnya wakaf dalam Islam.

b. Harta wakaf tidak boleh dijual atau dihibahkan atau diwariskan.

c. Syarat-syarat waqif (pemberi wakaf) perlu diperhatikan.

d. Pentingnya memberikan dana melalui wakaf kepada kaum muslimin.

e. Pentingnya mengadakan musyawarah dengan orang yang pandai untuk menetapkan pemanfaatan suatu harta atau cara pengelolaan suatu kekayaan.

\section{Syarat-Syarat dan Ketentuan Hukum Wakaf}

Wakaf adalah merupakan perbuatan hukum, yang untuk sahnya pelaksanaannya harus memenuhi rukun dan syarat-syarat yang ditetapkan, baik oleh hukum Islam maupun oleh peraturan perundangan-undangan. Sebagai perbuatan hukum, wakaf mempunyai rukun-rukun yang harus dipenuhi. Sebagaimana perbuatan hukum lainnya, wakaf yang tidak memenuhi rukunnya, seluruh atau sebagiannya, membuat perbuatan hukum tersebut menjadi batal demi hukum.

Rukun wakaf yang harus dipenuhi dalam melakukan perbuatan hukum wakaf ada 4 (empat), yaitu:

1. Waqif (orang yang mewakafkan harta);

2. Mauquf bih (barang atau harta yang diwakafkan);

3. Mauquf 'alaihi (pihak yang diberi wakaf/peruntukan wakaf);

4. Shighat (pernyataan atau ikrar wakif sebagai suatu kehendak untuk mewakafkan sebagian harta bendanya).

Masing-masing rukun ini mempunyai syarat-syarat yang harus dipenuhi dengan rincian sebaga brikut:

1. Waqif tersebut harus merdeka, berakal sehat, dewasa, tidak dilarang melakukan tindakan hukum seperti tidak berada di bawah pengampuan karena boros atau lalai.

2. Harta yang diwakafkan, syaratnya antara lain: harta yang diwakafkan harus berupa benda tetap karena wakaf itu untuk selamanya. Syarat benda yang diwakafkan lainnya seperti: telah ditentukan bendanya, baik ukurannya maupun sifatnya; benda yang diwakafkan milik waqif.

3. Pihak yang menerima wakaf syaratnya: harus menggunakan barang wakaf tersebut untuk kebaikan karena wakaf adalah amal perbuatan untuk mendekatkan kepada Allah; penerima perorangan/umum harus dapat memiliki harta yang diwakafkan kepadanya. Maka tidak sah wakaf kepada janin, mayat, hewan dan sebagainya, penerima harus orang Islam, maka tidak sah wakaf kepada orang kafir, kafir harbi dan murtad. Tetapi al-Imam al-Nawawi berpendapat, sah wakaf kepada kafir dzimmi. Tetapi ulama yang lain memberikan syarat, benda yang diwakafkan harus dapat dimiliki non muslim dan tidak mengandung unsur maksiat. Penerima wakaf harus untuk kepentingan umum yang tidak ada unsur maksiat.

4. Shighat (ikrar wakaf) adalah harus munjazah (terjadi seketika/selesai). Maksudnya, shighat itu menunjukkan terjadi dan terlaksananya wakaf seketika setelah ijab 
diucapkan atau ditulis. Tidak diikuti syarat batil yang dapat merusak hakekat wakaf. Tidak diikuti batas waktu tertentu, kecuali menurut salah satu pendapat ahli hukum Islam. Tidak mengandung pengertian mencabut atau membatalkan wakaf yang telah dilakukan.

\section{Definisi dan Sejarah Wakaf Tunai}

Dalam bahasa arab wakaf tunai disebut وقف النقود (waqfun nuqud), dan kata wakaf sudah didefinisikan pada awal bab ini.

Adapun al-nuqud, maka kata ini adalah bentuk plural (jamak) dari kata al-naqd, yang berarti memisahkan dirham dan mengeluarkan yang palsu darinya, dan juga disebutkan secara mutlak untuk membahsaka mata uang dari emas dan perak atau yang selainnya yang dipergunakan dalam transaksi. ${ }^{15}$ Sedangkan nuqud secara istilah ialah sesuatu yang dipergunakan oleh manusia sebagai barometer untuk mengukur nilai, dan sebagai sarana dalam bertransaksi dan menabung. ${ }^{16}$

Wakaf tunai dapat didefinisikan sebagai aktivitas menahan uang dan memberikan/menginfakkan manfaat yang dihasilkan sebagai profit (keuntungan) dari pengelolaannya.

\section{Sejarah Wakaf Tunai}

Terdapat beberapa tulisan yang berkaitan dengan sejarah awal mula munculnya dan masyhur-nya praktik dari wakaf tunai ini. Di antaranya menyebutkan bahwa wakaf tunai terjadi awal mula pada masa Dinasti Ayyubiyah, dan ada pula yang menyebutkan pada masa Khilafah Utsmaniyah.

Di antara pandangan tersebut adalah bahwa wakaf tunai mulai populer pada masa Dinasti Ayyubiyah di Mesir. Pada masa Dinasti Ayyubiyah di Mesir perkembangan wakaf sangat menggembirakan. Pada masa ini, wakaf tidak hanya terbatas pada benda tidak bergerak, tetapi juga benda bergerak semisal wakaf tunai. Tahun $1178 \mathrm{M} / 572 \mathrm{H}$, dalam rangka mensejahterakan ulama dan kepentingan misi mazhab Sunni, Salahuddin al-Ayyubi menetapkan kebijakan bahwa orang Kristen yang datang dari Iskandar untuk berdagang wajib membayar bea cukai. Tidak ada penjelasan, orang Kristen yang datang dari Iskandar itu membayar bea cukai dalam bentuk barang atau uang. Namun lazimnya bea cukai dibayar dengan menggunakan uang. Uang hasil pembayaran bea cukai itu dikumpulkan dan diwakafkan kepada para fuqaha' (juris Islam) dan para keturunannya. ${ }^{17}$

${ }^{15}$ Muhammad Mukarram Ibnu Manzhur, Lisanul Arab, Jilid IX, (Beirut: Dar Shadir, 1414 H), h. 425 .

${ }^{16}$ Ahmad bin Abdul Aziz al-Haddad, Waqf al-Nuqud wa Istitsmaruha. Tulisan ini belum diterbitkan sejak Muktamar Pertama tentang wakaf yang diselenggarakan oleh Universitas Umm al-Qura bekerja sama dengan Kementrian Islam, Wakaf, Dakwah dan Bimbingan Makkah alMukarramah tahun 1422 H, h. 6.

${ }^{17}$ Lihat, Drs. H. Sarmin, M.H. (Hakim). http://pabangil.pta-surabaya.go.id/ Diakses pada tanggal 1 Maret 2020. 
Kemudian ada juga pendapat yang menyatakan bahwa wakaf tunai mulai populer pada masa Dinasti Utsmaniyah. Boleh jadi awal muncul dan populernya wakaf tunai menuju eksistensinya yang menarik perhatian adalah pada masa Dinasti Utsmaniyah yang pertama, lebih tepatnya di Edirne (sebuah ibukota di Eropa Baru di masa Dinasti Utsmaniyah sebelim berpindah ke Anadhol) pada tahun 872 H/ $1423 \mathrm{M}$, yang mana hal ini menimbulkan perselisihan ahli fikih di kalangan Hanafiyyah, yang merupakan mazhab yang tersebar di dinasti tersebut, maka sebagian mereka memperbolehkan dan sebagian yang lain melarangnya. ${ }^{18}$

\section{Pandangan Ulama Tentang Wakaf Tunai}

Pada hakikatnya, mukaddimah dari perbedaan pendapat yang terjadi di antara para ulama dalam masalah wakaf tunai adalah berangkat dari pembagian wakaf itu sendiri, yaitu adanya waqaf manqul (yang bisa dipindahkan) dan ghairu manqul (yang tidak bisa dipindahkan). Maka dalam hal ini, untuk bentuk pembagian yang pertama, maka mereka sepakat akan kebolehannya, adapun bentuk yang kedua maka mereka sudah berbeda pendapat, ada yang membolehkan dan ada yang tidak memperbolehkan. Sedangkan pembahasan tentang wakaf tunai masuk dalam bentuk yang kedua ini yang dalam menanggapi pembahasan tentang wakaf tunai, maka para ulama pun dari berbagai macam mazhab telah berbeda pendapat dalam menetapkan hukum, dan hal yang mendasari perbedaan pendapat inilah adalah apakah benda yang diwakafkan harus bersifat kekal secara hakiki selama diambil manfaatnya, atau apakah dapat ditukar dengan benda yang lain yang nilainya sama dengan benda itu. Dalam artian, kekal secara maknawi selama masih bisa diambil manfaatnya.

Berdasarkan perbedaan pendapat tersebut, maka dalam hal ini terdapat rincian sebagai berikut:

1. Wakaf tunai tidak boleh secara mutlak, dan ini adalah pendapat sebagian Hanafiyyah dan Malikiyyah, dan termasuk yang diperkuat dalam mazhab Syafi'iyyah dan Hanabilah, dan alasan mereka karena tidak mungkin uang bisa dimanfaatkan kecuali dengan menghabiskannya atau menghilangkannya, sementara wakaf adalah menahan benda atau asal, oleh karena itu tidak boleh mewakafkan uang dan makanan. Ibnu Qudamah dalam kitab al-Mughniy berkata: "Sesuatu yang tidak bisa dimanfaatkan ketika bendanya tetap ada seperti dinar, dirham, makanan, minuman, lilin dan yang semisalnya tidak sah ujntuk diwakafkan menurut pandangan banyak ulama, kecuali apa yang diriwayatkan dari Malik dan al-Auza'iy. Dalam hal mewakafkan makanan Malik dan al-Auza'iy memandang kebolehannya, sekalipun ashab Malik tidak meriwayatknnya, dan hal ini tidak benar, karena wakaf itu adalah menahan pokok/asal dan memberikan hasilnya, dan sesuatu yang tidak

18 Lihat, Dr. Muhammad Libadan dan Dr. Muhammad Ibrahim Naqasiy dalam tulisan kedunya yang berjudul Nizham Waqf al-Nuqud wa Dauruhu fi Tanmiyah al-Marafiq alTarbawiyah wa al-Ta'limiyah, yang diajukan pada Seminar Internasional tentang UndangUndang Wakaf dan Pengelolaannya, Imlementasi dan Penerapannya, yang dilaksanakan pada tanggal 20-22 Oktober 2009 M/ 1-3 Dzulqa'dah 1430 H, yang diprakarsai oleh Markaz Idarah Fakultas Ahmad Ibrahim, Sekolah Tinggi Persatuan Umat Islam, International Islamic University Malaysia (IIUM), h. 3-4. 
bisa dimanfaatkan kecuali dengan merusaknya tidak bisa dijadikan wakaf. Dan ada juga pendapat yang menyatakan bahwa boleh mewakafkan dirham dan dinar dengan alasan bolehnya untuk disewakan, dan ini tidak benar karena manfaat bukanlah tujuan ketika diciptakan dengan memilikik nilai, olehnya itu dalam hal ini tidak ada jaminan ketika terjadi pengambilan secara paksa, sehingga tidak boleh diwakafkan. 19

2. Wakaf tunai hukumnya makruh, dan ini adalah pendapat yang lain dari mazhab Malikiyyah, disebutkan dalam Mawahibul Jalil: "Bahwasanya mewakafkan dinar dan dirham serta segala sesuatu yang tidak diketahui keberadaan bendanya ketika hilang hukumnya makruh". ${ }^{20}$

3. Wakaf tunai diperbolehkan dan ini adalah pendapat kebanyakan ulama dalam mazhab Hanafiyyah ${ }^{21,22,23,24}$ dan inilah yang masyhur dari mereka, dan juga pendapat lain dari mazhab Syafi'iyyah, dan juga satu riwayat dari Hanabilah dan diperkuat oleh Ibnu Taimiyyah ${ }^{25,26}$ dalam sebuah pendapatnya. Begitu juga Ibnu Syihab al-Zuhriy. Disebutkan pula dalam banyak kitab-kitab Hanafiyyah akan bolehnya wakaf tunai, bahkan Abu al-Su'ud al-Hanafiy mengarang sebuah risalah tentang hukum bolehnya wakaf tunai, yang beliau telah merinci dalil-dalil dan nukilan-nukilan yang menunjukkan akan bolehnya wakaf tunai.

Secara ringkas dapat disimpulkan bahwa ulama yang membolehkan wakaf dengan uang tunai beralasan sebagai berikut:

1. Pendapat Imam al-Zuhriy yang menyatakan bahwa mewakafkan dinar hukumnya boleh, dengan cara menjadikan dinar tersebut sebagai modal usaha kemudian keuntungannya disalurkan pada mauquf 'alaih. ${ }^{27}$

19 Abdullah bin Ahmad Ibnu Qudamah al-Maqdisi, Al-Mughniy fi Fiqh al-Imam Ahmad bin Hanbal al-Syaibaniy, Jilid VI, (t.p.: Dar al-Fikr, 1405 H), h. 262.

${ }^{20}$ Syamsuddin Abu Abdillah Muhammad bin Muhammad bin Abdurrahman al-Tarabulisiy al-Maghribiy al-Haththab, Mawahib al-Jalil li Syarhi Mukhtashar Khalil, Tahqiq Zakariya 'Umairat, Jilid VII, (Beirut: Dar Alam al-Kutub, 1423 H), h. 631.

${ }^{21}$ Lihat, Muhammad bin Abdul Wahid Ibn al-Hammam, Syarh Fath al-Qadir, Jilid VI (Cet. II; Beirut: Dar al-Fikr, t.th.), h. 219.

22، Alauddin al-Hashkafiy, Ad-Durar al-Mukhtar, Jilid IV, (Beirut: Dar al-Fikr, 1399 H/ 1979 M), h. 363.

${ }^{23}$ Muhammad bin Abdullah al-Khurasyi, Hasyiah al-Khurasyi, Jilid VII, (Beirut: Dar alKutub al-Ilmiyah, 1997 M), h. 80.

${ }^{24}$ Ibrahim Ali al-Syairaziy, Al-Muhadzdzab, Jilid I, (Beirut: Dar al-Ma'rifah, 1379 M), h. 447.

25 Ahmad bin Abdul Halim Ibnu Taimiyyah, Majmu' Fatawa Syaikh al-Islam Ibnu Taimiyyah, Jilid XXXI, (Madinah: Majma' Malik Fahd li Thiba'at al-Mushaf al-Syarif, 1416 H/ 1995 M), h. 234.

${ }^{266}$ Alauddin Ali Salman al-Mardaway, Al-Inshaf fi Ma'rifat al-Rajah min al-Khilaf, Tahqiq Muhammad Hasan Ismail, Jilid VII, (Cet. I; Beirut: Dar al-Kutub al-Ilmiyah, 1418 H/ 1997 M), h. 11. h. $20-21$.

${ }^{27}$ Abu Su'ud Muhammad, Risalah fi Jawazi Waqf al-Nuqud, (Beirut: Dar Ibn Hazm, 1997), 
2. Mutaqaddimin dari ulama mazhab Hanafi membolehkan wakaf uang dinar dan dirham atas dasar istihsan bi al-'urf berdasarkan atsar Abdullah bin Mas'ud radhiyallahu 'anhu:

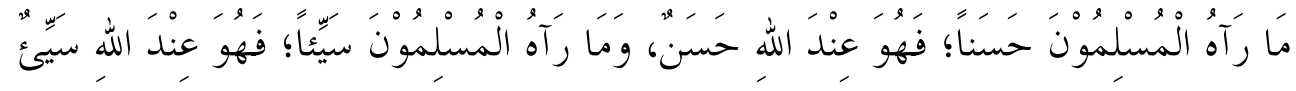

Artinya: "Apa yang dipandang baik oleh kaum muslimin maka dalam pandangan Allah adalah baik, dan apa yang dipandang buruk oleh kaum muslimin maka dalam pandangan Allah pun buruk" ${ }^{28}$

Sedangkan alasan ulama yang tidak memperbolehkan wakaf dengan uang tunai beralasan bahwa:

1. Bahwa uang zatnya bisa habis dengan sekali pakai. Uang hanya bisa dimanfaatkan dan dibelanjakan sehingga bendanya lenyap. Padahal inti dari wakaf adalah pada kesinambungan hasil dari modal/ harta yang tetap. Oleh karena itu ada persyaratan agar benda yang diwakafkan harus tahan lama dan tidak habis ketika dipakai.

2. Bahwa uang diciptakan sebagai alat tukar, bukan untuk ditarik manfaatnya dengan mempersewakan zatnya.

Dari dua pendapat tersebut di atas, maka pendapat yang lebih mendekati kebenaran adalah pendapat yang mengatakan wakaf tunai hukumnya boleh, karena tujuan disyariatkan wakaf adalah menahan pokoknya dan menyebarkan manfaat darinya. Dan wakaf uang yang dimaksud bukanlah zat uangnya tetapi nilainya, sehingga bisa diganti dengan uang lainnya, selama nilainya sama. Sehingga wakaf uang hakekatnya sama dengan wakaf tanah, yakni harta pokoknya (yang berupa nilai dari uang itu) tetap dan hasilnya dapat dikeluarkan. Dengan mekanisme wakaf uang yang telah ditentukan, pokok harta akan dijamin kelestariannya dan hasil usaha atas penggunaan uang tersebut dapat dipakai untuk mendanai kepentingan umat.

Dalam al-Is'af fi Ahkam al-Awqaf, al-Tharabulusiy menyatakan: "Sebagian ulama klasik merasa aneh ketika mendengar fatwa yang dikeluarkan oleh Muhammad bin Abdullah al-Anshari, murid dari Zufar, sahabat Abu Hanifah, tentang bolehnya berwakaf dalam bentuk uang kontan dirham atau dinar, dan dalam bentuk komoditas yang dapat ditimbang atau ditakar, seperti makanan gandum. Adapun yang membuat mereka merasa aneh adalah karena tidak mungkin mempersewakan benda-benda seperti itu, oleh karena itu mereka segera mempersoalkannya dengan mempertanyakan apa yang dapat kita lakukan dengan dana cash dirham. Atas pertanyaan ini, Muhammad bin Abdullah al-Anshari menjelaskan dengan mengatakan: "Kita investasikan dana itu dengan cara mudharabah dan labanya kita sedekahkan. Kita jual benda makanan itu, harganya kita putar dengan usaha mudharabah kemudian hasilnya disedekahkan."29

${ }^{28}$ Wahbah al-Zuhaili, Al-Fiqh al-Islam wa Adillatuhu, Jilid VIII, (Damaskus: Dar al-Fikr, 1985), h. 162.

${ }^{29}$ Burhanuddin Ibrahim Musa Ali al-Tharabulusiy, Al-Is'af fi Ahkam al-Awqaf, (Beirut: Dar al-Ra'id al-Arabiy, 1401 H/ 1981 M), h. 26. 
Kebolehan wakaf tunai ini telah ditetapkan pada konferensi ke- 15, Majma' alFiqh al-Islami OKI, No. 140 di Mascot, Oman, pada tanggal 14-19 Muharram 1425 H/ 6-11 Maret $2004 \mathrm{M}^{30}$

Selain itu, Majelis Ulama Indonesia (MUI) juga telah mengeluarkan fatwa kebolehan wakaf tunai, pada tanggal 11 Mei 2002.

Wakaf Tunai juga sudah dituangkan dalam Peraturan Menteri Agama No. 4/ 2009 dan dalam Undang-Undang nomor 41 tahun 2004 diatur dalam pasal 28 sampai pasal 31 .

\section{Urgensi dan Sasaran Wakaf Tunai}

Secara jelas kita bisa melihat beberapa urgensi dari wakaf tunai pada masa kita sekarang ini, di antaranya sebagai berikut:

1. Kita biasa mendapatkan banyak orang yang tidak memiliki aset untuk ditukar dengan barang, atau pembangunan masjid-msajid atau rumah-rumah untuk diwakafkan, tetapi mereka punya uang yang mana kita memberikan kesempatan kepada mereka untuk menjalankan proyek itu yang mana hasilnya bisa dibagikan kepada fakir miskin.

2. Wakaf tunai kebanyakan berdiri di atas asas jamaah/kelompok yang mana hal itu bisa mewujudkan suatu lembaga wakaf, karena hal itu bias menjadi penyedia sumber harta wakaf yang besar yang bisa memberikan modal dan memudahkan dalam menjalankan proyek-proyek ekonomi dan pendidikan yang bersakala besar, oleh karena itu wakaf tunai dapat di anggap sangat cocok dengan kondisi kita sekarang ini dibandingkan dengan wakaf yang bersifat pribadi (yang sangat terbatas).

3. Dengan adanya wakaf tunai hal itu memudahkan kita untuk memilih proyek-proyek dan bentuk-bentuk pengelolaan yang dibutuhkan masyarakat pada hari ini, seperti pembangunan sekolah, rumah sakit, fasiltas umum yang mana terkadang pihak negara biasa kesulitan untuk menanganinya, seperti perawatan jalan dan pengadaan pabrik-pabrik dan yang lainnya.

Adapun sasaran wakaf tunai, maka setidaknya ada empat tujuan dari wakaf tunai, yaitu:

1. Kemanfaatan bagi kesejahteraan pribadi (dunia dan akhirat).

2. Kemanfaatan bagi kesejahteraan keluarga (dunia dan akhirat).

3. Pembangunan sosial.

4. Membangun masyarakat sejahtera, jaminan sosial bagi kelompok miskin, dan jaminan keamanan sosial bagi kelompok kaya.

\section{KESIMPULAN}

Dari penjelasan di atas, dapat disimpulkan beberapa hal sebagai berikut:

${ }^{30}$ Lihat situs resmi Majma' al-Fiqh al-Islamiy: http://www.iifa-aifi.org/2157.html Diakses pada 16 April 2020. 
1. Wakaf adalah تحبيس الأصل وتسبيل المنفعة yaitu menahan asal dan memberikan manfaat. Sedangkan yang dimaksud dengan wakaf tunai adalah aktivitas menahan uang dan memberikan atau menginfakkan manfaat yang dihasilkan sebagai profit (keuntungan) dari pengelolaannya.

2. Sejarah tentang awal mula wakaf tunai mulai populer di tengah masyarakat muslim ada dua versi, yaitu pendapat yang mengatakan bahwa hal itu terjadi pada masa Dinasti Ayyubiyah, dan pendapat yang lain menyatakan bahwa hal itu terjadi pada masa Dinasti Utsmaniyah. Namun dari kedua pendapat tersebut penulis belum mendapatkan literatur yang valid tentang pendapat yang lebih tepat dari kedua pernyataan di atas.

3. Ulama berbeda pendapat dalam menetapkan hukum tentang wakaf tunai. Sebagian di kalangan ulama berpendapat akan bolehnya wakaf tunai tersebut. Sebagian yang lainnya memandang hukumnya makruh. Bahkan adapula ulama yang mengharamkannya. Adapun penulis lebih cenderung kepada pendapat yang menyatakan akan kebolehannya.

4. Adapun urgensi dan sasaran dari wakaf tunai adalah untuk meningkatkan perekonomian dan mendapatkan kemaslahatan di dunia dan akhirat.

\section{DAFTAR PUSTAKA}

'Alauddin al-Hashkafiy. (1979). Ad-Durar al-Mukhtar, Jilid IV. Beirut: Dar al-Fikr, h. 363.

Al-Bukhariy, Muhammad bin Ismail. (1422 H). Shahih al-Bukhariy, Jilid III. Beirut: Dar Tauq al-Najah, h.198.

Al-Khurasyi, Muhammad bin Abdullah. (1997). Hasyiah al-Khurasyi, Jilid VII. Beirut: Dar al-Kutub al-Ilmiyah, h. 80.

Al-Maghribiy, Muhammad bin Muhammad bin Abdurrahman. (1992). Mawahib al-Jalil Syarh al-Mukhtshar al-Jalil, Jilid VI. Kairo: Dar al-Fikr, h. 18.

Al-Maqdisi, Abdullah bin Ahmad Ibnu Qudamah. (1981). Al-Mughniy, Jilid VI. Riyadh: Maktabah al-Riyadh al-Hadisah, h. 185.

Al-Mardaway, 'Alauddin Ali Salman. (1997). Al-Inshaf fi Ma'rifat al-Rajah min alKhilaf, Tahqiq Muhammad Hasan Ismail, Jilid VII, Cet. I. Beirut: Dar al-Kutub alIlmiyah, h. 11.

Al-Naisaburi, Muslim bin Hajjaj. (1954). Shahih Muslim, Jilid V. Beirut: Dar Ihya' alTurats al-Arabi, h. 1255.

Al-Sarkhasiy, Muhammad bin Abi Sahal. (1406 H). Al-Mabsuth, Jilid XII. Beirut: Dar al-Ma'rifah, h. 27. 
BUSTANUL FUQAHA: Jurnal Bidang Hukum Islam

Vol. 1, No. 1 (2020) : Hal. 79-92

Website: https://journal.stiba.ac.id

Al-Syairaziy, Ibrahim Ali . (1379 H). Al-Muhadzdzab, Jilid I. Beirut: Dar al-Ma'rifah, h. 447.

Al-Tharabulusiy, Burhanuddin Ibrahim Musa Ali. (1981). Al-Is'af fi Ahkam al-Awqaf. Beirut: Dar al-Ra'id al-Arabiy, h. 26.

Al-Zuhaili, Wahbah . (1985). Al-Fiqh al-Islam wa Adillatuhu, Jilid VIII. Damaskus: Dar al-Fikr, h. 162.

Aziz, M.W. (2017). Wakaf Tunai dalam Perspektif Hukum Islam. Internasional Journal Ihya' 'Ulum al-Din, Vol. 19, No. 1, p. 1-24. DOI: 10.21580/ihya.18.1.1740.

Hatta, M. Wakaf Tunai dalam Perspektif Ulama Mujtahid. Jurnal Al-Qanun, Vol. 20, No. 2, p. 104-121.

Ibnu Manzhur, M.M. (1414 H). Lisanul Arab, Jilid IX. Beirut: Dar Shadir, h. 359.

Ibnu Manzhur, Muhammad Mukarram. (1414 H). Lisanul Arab, Jilid IX. Beirut: Dar Shadir, h. 425.

Ibnu Qudamah al-Maqdisi, Abdullah bin Ahmad. (1405 H). Al-Mughniy fi Fiqh al-Imam Ahmad bin Hanbal al-Syaibaniy, Jilid VI. Dar al-Fikr, h. 262.

Ibnu Taimiyyah, Ahmad bin Abdul Halim. (1995). Majmu' Fatawa Syaikh al-Islam Ibnu Taimiyyah, Jilid XXXI. Madinah: Majma' Malik Fahd li Thiba'at al-Mushaf alSyarif, h. 234.

Iskandar, A., Aqbar, K. (2019). Reposisi Praktik Ekonomi Islam: Studi Kritis Praktik Ekonomi Islam di Indonesia. NUKHBATUL 'ULUM: Jurnal Bidang Kajian Islam, 5(1), 39-53. https://doi.org/10.36701/nukhbah.v5i1.68.

Kamal, M. (2015). Wakaf Tunai Menurut Pandangan Fiqh Syafi'iyah dan Fatwa Majelis Ulama Indonesia No. 2 Tahun 2002 Tentang Wakaf Uang. Jurnal Ilmiah Islam Futura, Vol. 15., No. 1, p. 93-110.

Muhammad bin Abdul Wahid Ibn al-Hammam. (t.th.). Syarh Fath al-Qadir, Jilid VI, Cet. II. Beirut: Dar al-Fikr, h. 219.

Muhammad, Abu Su'ud. (1997). Risalah fi Jawazi Waqf al-Nuqud,. Beirut: Dar Ibn Hazm, h. 20-21.

Nawawi, M.A. (2016). Pengembangan Wakaf Uang Tunai sebagai Sistem Pemberdayaan Umat dalam Pandangan Ulama Konvensional dan Kontemporer. Jurnal Fikri, Vol. 1, No. 1, p. 183-210. 
BUSTANUL FUQAHA: Jurnal Bidang Hukum Islam

Vol. 1, No. 1 (2020) : Hal. 79-92

Website: https://journal.stiba.ac.id

Pusparini, M.D. (2016). Konsep Wakaf Tunai dalam Ekonomi Islam: Studi Pemikiran Abdul Mannan. Falah: Jurnal Ekonomi Syariah, Vol. 1, No. 1, p. 15-28.

Syamsuddin Abu Abdillah Muhammad bin Muhammad bin Abdurrahman al-Tarabulisiy al-Maghribiy al-Haththab. (1423 H). Mawahib al-Jalil li Syarhi Mukhtashar Khalil, Tahqiq Zakariya 'Umairat, Jilid VII. Beirut: Dar Alam al-Kutub, h. 631.

Tho'in, M., dan Prastiwi, I.E. (2015). Wakaf Tunai Perspektif Syariah. Jurnal Ilmiah Ekonomi Islam, Vol. 01, No. 01, p. 61-74. 